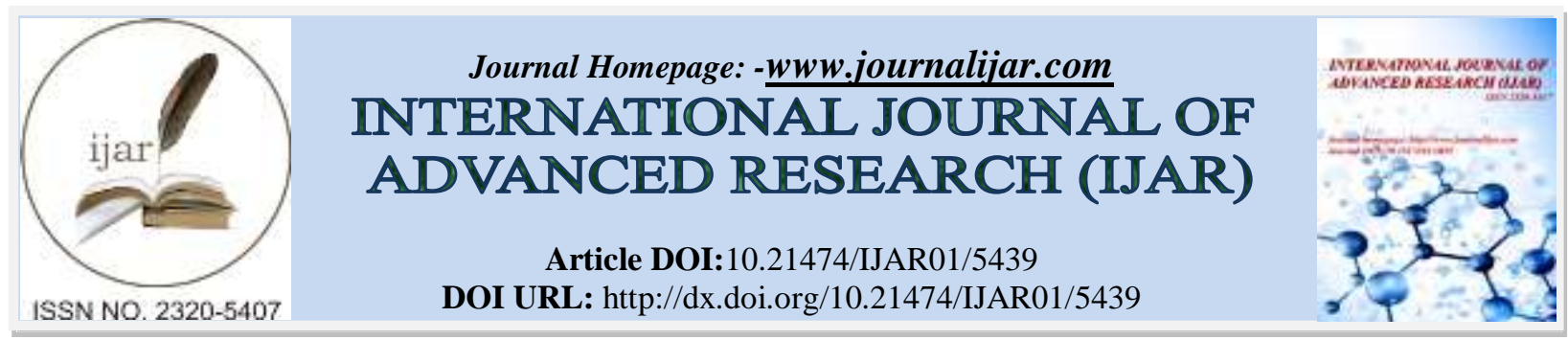

RESEARCH ARTICLE

\title{
IMPLEMENTATION OF COOPERATIVE LEARNING TYPE ROTATING TRIO EXCHANGE(RTE) IN SOCIAL STUDIES.
}

\author{
Rahayu, Fajar Surya Hutama,Imam Muchtar and Risa Dwi Naila Rizqi. \\ Elementary Education Study Program, University of Jember, Indonesia.
}

\section{Manuscript Info}

Manuscript History

Received: 16 July 2017

Final Accepted: 18 August 2017

Published: September 2017

Key words:-

Cooperative learning, Rotating Trio

Exchange, social studies, student activity, learning outcome

\begin{abstract}
The purpose of this research is to describe the implementation of cooperative learning in elementary school class. The type used is Rotating Trio Exchange (RTE) for $4^{\text {th }}$ grade students in elementary school in the topic of social studies. This research is class room action research based on qualitative descriptive approach. The data collection methods are observation and test. Learning process using cooperative learning with RTE type made the students be more active. As a result, the category of students' activity increase from inactive to active and the learning outcome in social studies also increase from fair category to excellent
\end{abstract}

Copy Right, IJAR, 2017,. All rights reserved.

\section{Introduction:-}

Social science includes integration of concepts across field of social studies. It is unlike social studies which are academic disciplines such as anthropology, sociology, history, politic, economics, psychology, geography, and so on. Thus social science is not an academic sub-discipline but it is an educational program (Somantri, 2001: 89).

There are several strategies to teach social skills to students by social science, such as implmentingcooperativelearning. Also the aspect of teachers' teaching skills that are required to be increased in globalization is learning how to present social science usingeither relevant approaches and models to what the learning objectives are (Wiriaatmadja, 2002: 277).

The result of research conducted by Al Mukhtar (2004), Aziz (2002), and Somantri (2001) suggests that social studies in school are always presented in a factual, dried concept, teachers only chasing the target curriculum achievement, and are not concerned with the process, so that it is always boring. Aziz (2002) also states that in social studies, the process is critical. In social studies, students are expected to acquire knowledge and experiences in applying that knowledge in daily life, democratic. Also it is practicing thinking critically and doing problem solving.

Social science as one of subjects at school has an important role in preparing students become qualified. Social science is one of subjects given in elementary school examining past events, facts, concepts, and generalizations related to social issues which contains geography, history, sociology and economics. By studying social science, students are guided to become Indonesian citizens who are democratic, accountable, and peaceful. Thus the quality of social science should be increased. Increasing social science outcomes is expected to create a positive impact in improving the quality of education in Indonesia. 
The result of observations in implementing social scienceon $4^{\text {th }}$ grade students of SDN Tegalgede 03 Jember, Indonesia indicate that teaching methodscommonly used are lectures, discussions and assignments, and worksheet. In learning process, the teacher does not use certain learning model. Learning is centered on the teacher (teachercentered). Only few students who are active in learning process. When some students isstandingin front of the class, some other students seem not to listen or pay attention to them. Students' activities are quite good, although there are some students who seem less enthusiastic. Even some students seem play something by themselves in learning process.

The students' learning outcomes of social science at SDN 03 Tegalgedeare fairly good. Minimum score required is 70. There are 4 of 27 students reachingthe minimum score (14.81\%), and 23 students not reaching the minimum score $(85.18 \%)$, which score range is $57-69$.

Based on this conditions, it is necessary to have alternative solution to increase students' activity and learning outcomes. One of its solutions is applying student-centered activity and giving students a chance to develop their own potencies completely. Cooperative learning model is very suitable to be applied in social science, because in social science it does not only know and memorize the theories, but it also understand and is able to analyze. This this learning model students can express their thoughts, exchange their ideas, work together if their friends find difficulties. This can increase students' motivation in examining and mastering the material

There are several types which can be applied in cooperative learning. One of them is a cooperative learning typeRotating Trio Exchange (RTE). Isjoni (2010: 59) says that cooperative learning type RTE isa learning model which consists of 3 students in one group and they are given number 0,1 , and 2 . Number 1 moves clockwise, number 2 is opposite of number 1 and number 0 stay at the place. Each group is given questions to discuss together. After that, the group is rotated again and there is a new trio. Each new trio isgiven the new questions to discuss together. It is conducted by giving more sophisticated question.

Cooperative learning type RTE is learning model which students can work together, help each other to learn information or skills. The assessment ofstudents' improvement is assessed by their working in groups. Cooperative learning type RTE is an effective way to change pattern of learning process in the classroom. This cooperative learning type has an explicit procedure to give students many more chances to think, respond and help each other. Cooperative learning can help students actively in learning processs, so that students do not feel bored of social sciencewhich usually only focuses on the material. Each student has a responsibility on each, even in different group. Students can build their own knowledge and improve their own understanding, so that what they get can be more meaningful and will be able to increase their activity and learning outcomes.

\section{Rearch Methods:-}

This study uses qualitative descriptive approach which aims to describe or explain urgent problems occurring nowadays. This study only describes a situation occuring. It is the implementation of cooperative learning type RTE on the $4^{\text {th }}$ grade students in social science. The subjectsare social problems around SDN Tegalgede 03 Jember.

The subjects are $4^{\text {th }}$ grade students of SDN Tegalgede 03,Jember who are in the second semester of 2015/2016. There are 27 students consisting of 10 male students and 17 female students. The $4^{\text {th }}$ grade is chosen to be a research subject, because it is high level class. The implementation of cooperative learning is expected to be maximal. Additionally,learning method on social science applied atclasshas not been optimal yet and also the teacher has not used learning model which can attract the students.

The method used in this research are observation, documentation, and interviews. An observation method is used to record, observe, listen, feel, gather, and capture all phenomena, data, and information about cases under investigation (Salim, 2005). Observation method is conducted to gain information. In this study, observation method is used to observe the symptoms which appear on the students in learning process including students' questioning, the ability of students respond the questions and so on.

Interviews are conducted to teachers and students. Interviews to teachers aiming to get information about learning method in social sciencebefore implementing cooperative learning type RTE. Interviews to students before and after cooperative learning type RTE is applied. Test is a method used to measure students'improvement after participating in learning process using cooperative learning type RTE. The type of tests used areobjective test and subjective test. 
This test aims to measure the cognitive and define the students' learning outcomes after taking learning process. Documents are used to get data about learning process describing the steps of cooperative learning type RTE.

Percentage analysis of students' activity during the implementation of cooperative learning type RTE in social science uses the formula below.

\section{Percentage ofstudents' learning activities:-}

Percentage ofindividual student' learning activities uses the following formula.

\section{Description:-}

$$
\mathrm{Pa}=\frac{\mathrm{A}}{\mathrm{N}} \times 100
$$

$\mathrm{Pa}=$ Score achievement of student's learning activities

$A=$ Number of learning activity score achieved by students

$\mathrm{N}=$ Total maximum score of student learning activities

Percentage classical using the following formula.

The percentage of students' activity $($ classical $)=\frac{\text { Numberof } \text { students' }^{\prime} \text { activities }(\text { bycategory })}{\text { Thetotalnumberof }_{\text {students }}} \times 100 \%$

Table 1:-Criteria of Learning Activities

\begin{tabular}{|c|c|}
\hline Criteria of Learning Activities & Category Activeness \\
\hline Very active & $91-100$ \\
\hline Active & $71-90$ \\
\hline Fair & $41-70$ \\
\hline Inactive & $21-40$ \\
\hline Very Inactive & $0-20$ \\
\hline
\end{tabular}

Source: Masyhud (2014: 298)

Analysis of students' learning outcomes:-

Student learning outcomes can be obtained by the following formula.

Description:-

$$
\mathbf{P a}=\frac{\mathbf{A}}{\mathbf{N}} \times \mathbf{1 0 0}
$$

$\mathrm{P}=$ student's score achieved

$\mathrm{n}=$ number of scores obtained by students' learning outcomes

$\mathrm{N}=$ total of maximum score of student's learning outcomes

Percentage of students' learning outcomes obtained with the following formula.

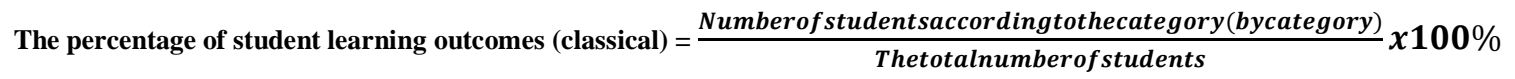

Table 2:-Criteria of Learning Outcomes

\begin{tabular}{|c|c|}
\hline Criteria of Learning Outcomes & Score Range \\
\hline Excellent & $80-100$ \\
\hline Good & $70-79$ \\
\hline Fair & $60-69$ \\
\hline Poor & $40-59$ \\
\hline Very Poor & $0-39$ \\
\hline
\end{tabular}

Source: Masyhud (2014: 295) 


\section{Results And Discussion:-}

The study begins with planning: (1) to develop a learning tool covering the syllabus and lesson plan; (2) to prepare materials and tools for cooperative learningtype RTE; (3) to create a research instrument, namely observation and interviews to both the teacher and student and also to create worksheet for students; (4) to prepare a group worksheet and individual test; and (5) to create an answer key, assessment and scoring guidelines. Learning activities are conducted in two meetings. The observation is conducted during learning process and test is conducted at the end of the lesson.

\section{The first meeting:-}

Learning process on this meeting is adjustedto lesson plan which has been arranged by applying cooperative learning type RTE. These are learning activities conducted below.

\section{Introduction:-}

The teacher enters the classroom and says hello. The teacher asks the chairman to lead to pray. The students take a seat and is ready to start the class. The teacher makes a deal with the students that during the learning process, all students should be discipline and focus on the material presented by the teachers. The teachers give students motivation to come forward and speak. The teacher also announce that students who are active and get good grades will get a reward. The preliminary activity occurs during around 10 minutes. The teacher reminds the students about the material which has been studied previously. The teacher also does aperception, gives motivation to students and deliver learning objectives.

\section{Core activity:-}

Core activity occur about 50 minutes. The teacher explains the materials on social issues about school environment. The teacher thereupon categorizes students consisting of 3 students who are consecutively numbered starting from 0 , 1, 2. The teachers does not group students by student's id number, but the teacher groups high-ability students with low-ability students, so that high-ability students can become peer tutors for their friends. Then the teacher give cap numbered $0,1,2$ to each group member.

The teacher distributes the worksheet to each group members for discussion. The teacher also gives instructions and provide time for students to discuss worksheet rotation activity groups 1 . During the discussion, the teacher monitors students' activity. When time is over, each group rotates with other groups to form a new group. In the second rotation, studenst does the worksheets rotation group 2. The students actively cooperate with their friends group discussion.

The next stage is the teacher ask one of the groups presenting the results of discussion, while other groups give questions and responses. Each group is given around 5 minutes to present the results of discussion, respond and provide questions to the group who does the presentation. When making a presentation, the students dare to present the results of discussion and the teacher does not need to persuade the students to make a presentation to the class. The teacher asks the other groups to make presentations and so on.

When time is over, the teacher gives feedback and performance assessment to all groups which have made a presentation. The teacher also give chances to other groups to ask and respond. It seems the students have many questions, because they all have different answers and provide feedback to the grouppresentating the material. The students also give feedback to the group presenting the materials. Some groups which have not presented any materials yet have to do it next meeting.

The learning process is very conducive and the students looks happy and excited in learning model applied by the teacher. The teachers provide reinforcement to what has been delivered and the students note important things explained by the teacher.

\section{Closing:-}

At the end, the teacher ask the students to make conclusion about the material which has been studied. The teachers provide opportunities for students to inquire material that has not been understood. The teacher interviews the students to test students' understanding. The teacher asks the chairman to lead to pray. Then the teacher closes the class and say goodbye to the students. 


\section{The second meeting:- \\ Introduction:-}

This is conducted during around 10 minutes. The teacher enters the classroom and says hello. The teacher asks the chairman to lead to pray. The students take a seat and is ready to start the class. The teacher tells the class president to lead pray his friends. The teacher also does aperception, gives motivation to students and deliver learning objectives.

\section{Core Activity:-}

Core activity is conducted during around 50 minutes. The teacher reviews the material studied in previous meeting. The teacher interviews the students to test their understanding. The next activity is continuing the presentation delivered by some groups which have not delivered any materials yet. As in the first meeting, each group is given around 5 minutes to present the result of discussion, respond and provide questions. The presentation is delivered by all groups. The teacher gives feedback and assessment to the group which has presented a material. Then the teacher discusses about worksheet with the students. After finishing the presentation, the teacher prepare post test and give an explanation about the rules to do it. The students seems does the test seriously. When time is over, the teacher asks the students to submitworksheet.

\section{Closing:-}

At the end, the teacher guides the students to make a conclusion of what they have studied. The teacher also gives the students chances to ask about material they have not understood yet. In this activity, the teacher interviews the students to test their understanding. The teacher gives a reward to the most active group. The teacher gives motivations and conveys impressions about the learning process.

\section{Student's activity:-}

The observation is conducted to observe the students' learning activities during learning process when implementing cooperative learning type RTE examining social problems in around school environment. In this activity, the researcher is accompanied by three observers. Each of three groups are observed by an observer. Based on students' learning activity data, it is gained the result of analysing students' learning activities for each indicator below.

Table 3:- Analysis Results Per Student Activity Indicator

\begin{tabular}{|c|l|c|c|}
\hline No. & \multicolumn{1}{|c|}{ Indicators } & $\begin{array}{c}\text { Students' Learning Activities } \\
\text { Percentage }\end{array}$ & $\begin{array}{c}\text { Average of Classical Students' } \\
\text { Activeness Percentage }\end{array}$ \\
\hline 1. & $\begin{array}{l}\text { Listening to the teacher's } \\
\text { explanations }\end{array}$ & $83.9 \%$ & $80.4 \%$ \\
\hline 2. & Working in group & $85.1 \%$ \\
\hline 3 & Solving problems & $80.2 \%$ \\
\hline 4. & $\begin{array}{l}\text { Responding the result of } \\
\text { discussions. }\end{array}$ & $76.5 \%$ \\
\hline 5. & $\begin{array}{l}\text { Asking and expressing } \\
\text { opinions }\end{array}$ & $77.7 \%$ \\
\hline
\end{tabular}

Based on the table above, it can be made as a diagram of students' learning activities for each indicator below.

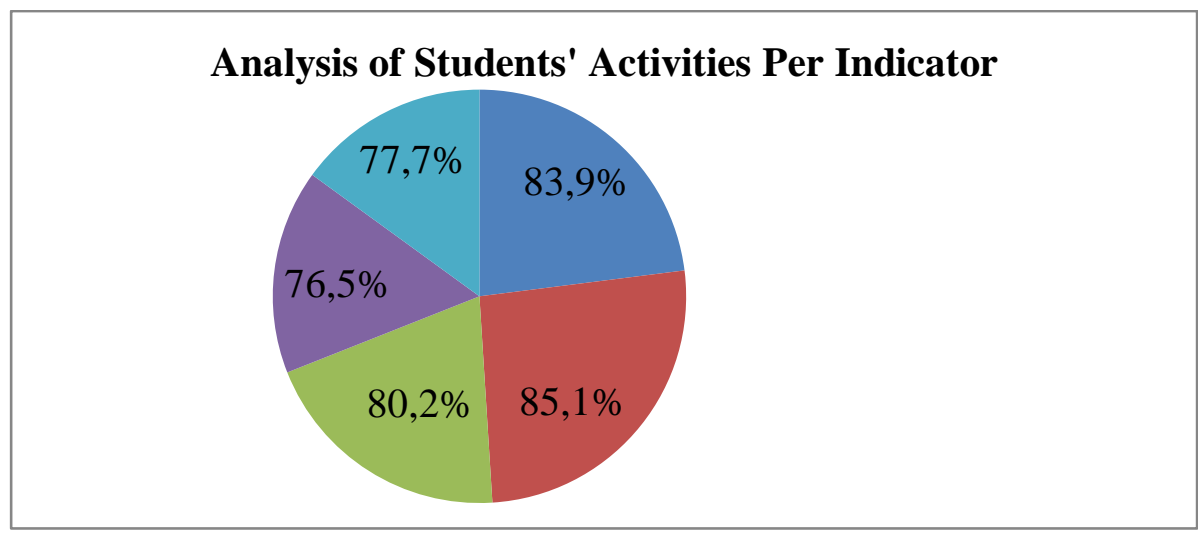

Figure 1:-Analysis of Student Activities. 
If it is adjusted to the criteria of students' learning activities on table 1, it is gained the data below.

Table 4:-Results of Analysing Students' Learning Activities Per Category

\begin{tabular}{|c|c|c|c|}
\hline Categoriesof Activeness & $\begin{array}{c}\text { Percentage of } \\
\text { Activeness }\end{array}$ & $\begin{array}{c}\text { Number of } \\
\text { Students }\end{array}$ & $\begin{array}{c}\text { Percentageof Students' } \\
\text { Activeness }\end{array}$ \\
\hline Highly Active & $91-100$ & 12 & $40.7 \%$ \\
\hline Active & $71-90$ & 7 & $29.6 \%$ \\
\hline Fair & $41-70$ & 6 & $29.6 \%$ \\
\hline Less Active & $21-40$ & 2 & $0.0 \%$ \\
\hline Very Less Active & $0-20$ & 0 & $0.0 \%$ \\
\hline Total & & $\mathbf{2 7}$ & $\mathbf{1 0 0}$ \\
\hline
\end{tabular}

Based on the table above, it can be made as a diagram of students' learning activity improvement below.

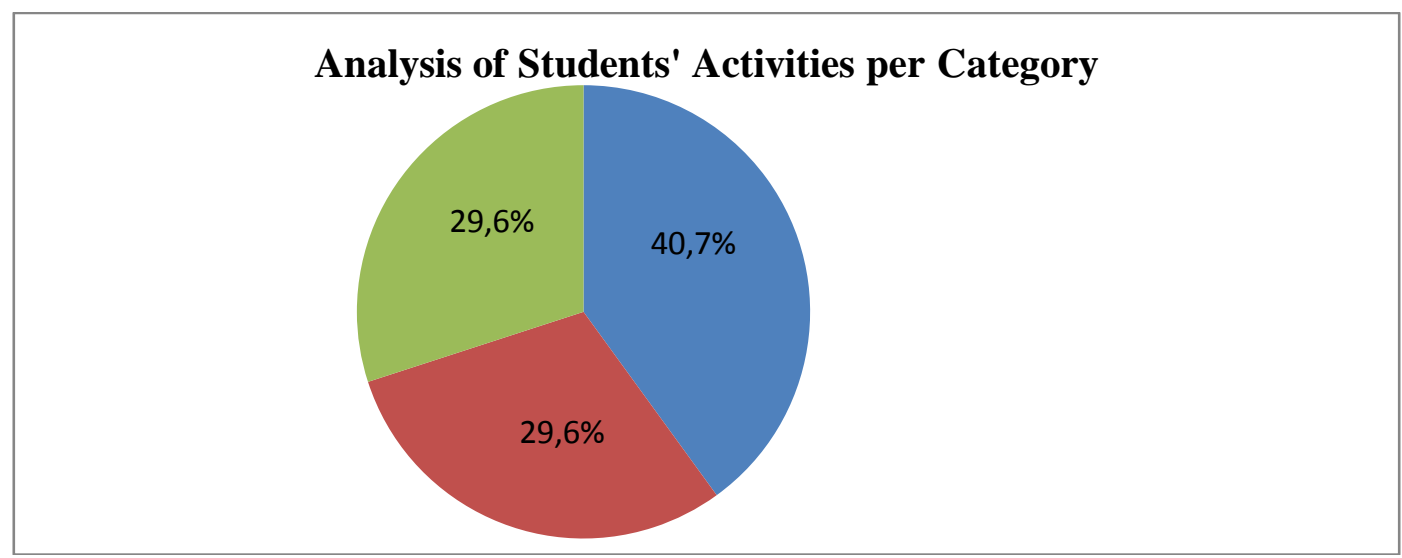

Figure 2:-Diagram of Analysing Students’ Activities Per Category

\section{Learning Outcomes:-}

Learning outcomes are gained from tests. Before implementing cooperative learning type RTE, the average of students' learning outcomes percentage is $62.6 \%$, after implementing cooperative learning type RTE, the average of students' learning outcomes percentage becomes $81.3 \%$ (excellent category) .

Table 5:-Result of Analysing Students' Learning Outcomes Per View Student

\begin{tabular}{|l|c|c|c|}
\hline Category of Learning Outcomes & Score Range & Number of Students & Percentageof Students' Activeness \\
\hline Excellent & $80-100$ & 19 & $70.3 \%$ \\
\hline Good & $70-79$ & 6 & $22.2 \%$ \\
\hline Fair & $60-69$ & 2 & $7.4 \%$ \\
\hline Poor & $40-59$ & 0 & $0.0 \%$ \\
\hline Very Poor Total & $0-39$ & 0 & $0.0 \%$ \\
\hline \multicolumn{2}{|c|}{} & $\mathbf{2 7}$ & $\mathbf{1 0 0 \%}$ \\
\hline
\end{tabular}

Based on the table, it can be made as diagram of students' learning outcomes improvement below. 


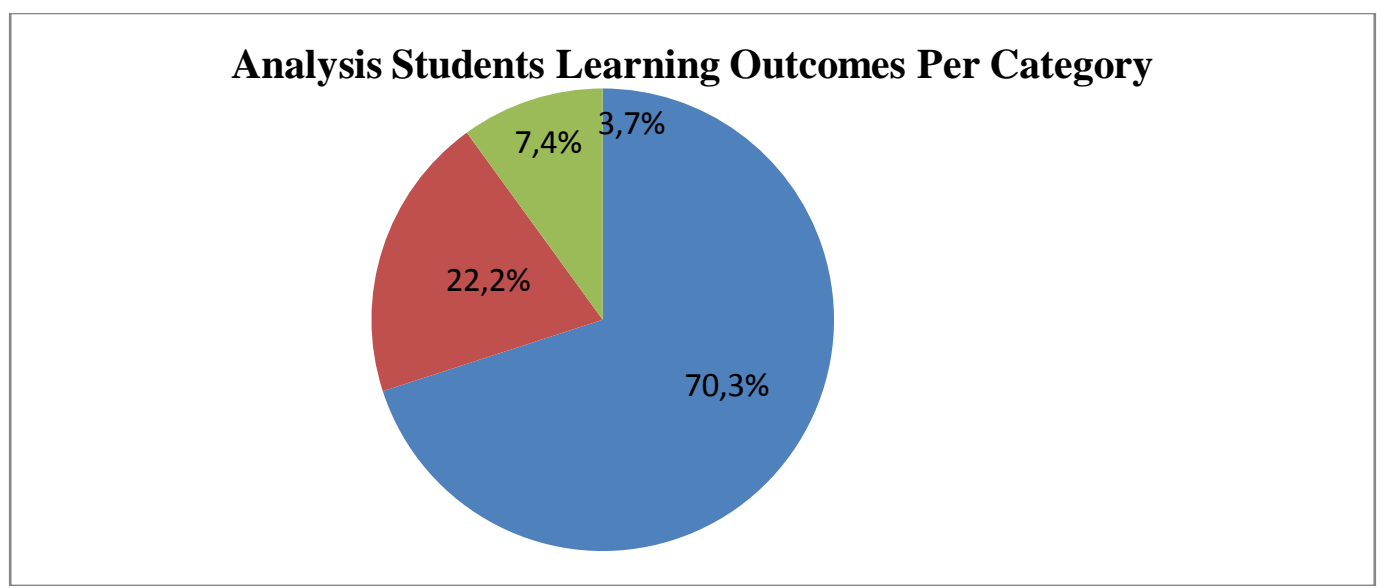

Figure 3:-Analysis of Students' Learning Outcomes Per Category

The result of interviewing several students indicates the students are very pleased with the implementation of cooperative learning type RTE in social science. According to the students, learning process is so fun, because there is a group rotation which makes them all more diligent to cooperate with their friends. The rotation also makes students more active, because they do not only stay on their seats. The $4^{\text {th }}$ grade students who have high achievement feel happy to take the class when the teacher implements cooperative learning type RTE, because it makes them all not feel embarrased to have presentation in front of the class, dare to ask about the materials which have not understood yet, and give responses. Low-achievement students also says that they feel happy in learning process. It is not boring because they usually only listen to teacher's explanation which makes them all bored. Based on some of these opinions, it can be concluded that students can catch up the material easily by using cooperative learning type RTE.

\section{Discussion:-}

This study aims to get information about $4^{\text {th }}$ students' activities and results in SDN Tegalgede 03, Jember using cooperative learning type RTE on social problems in around school environment. Based on the result of observations toward students' activities before cooperative learning type RTE implemented, it is known that the students is quite active. The score average of students' activeness is $48.4 \%$ and the score average of students'middle test is quite good. It is around $62.6 \%$.

Based on the result of observation toward students' learning activities indicate that it belongs to active category. The percentage of the students' learning activity score becomes 80.7 (active category). This is because the students more active on social science. Grouping between high achievent students and low achievement students make them help each other and also cooperate well.

The implementation of cooperative learning type RTE on social science can make students more active and happier during learning process. The students' activities are good enough. The students do not feel embrassed to deliver their own opinions or to give response to the presentation. Presenting the result of discussion make the students accustomed to being active at class. The group rotation also make them not bored to discuss something. It is sure that grouping between high avhievement students and low achievement students can make discussion run well, because the high achievement students can be peer tutor for their friends who have low achievement.

There are some results of the research about the implementation of cooperative learning type RTE below.

1. When grouping the students, the teacher need to group between high avhievement students and low achievement students can make discussion run well, because the high achievement students can be peer tutor for their friends who have low achievement

2. The implementation of cooperative learning type RTE on social science can make students happy to take the class.

\section{Conclusion:-}

The implementation of cooperative learning type RTE on social studies can improve students' learning activities. 
The average achievement of students' learning activities based on the results of preliminary observations shows 48.4\% (classified inactive), and after implementing cooperative learning type RTE, it becomes $80.7 \%$ (classified as active category).Students' learning outcomes increased from62.6 (fair), to 81.3 (exellent).

\section{References:-}

1. Al Muchtar, S. 2004. Thinking and Value Development in Social Science Education. Bandung: GelarPustakaMandiri.

2. Aziz, W. 2002. Challenges of Social Science Education Learning In schools, JPIS No. 19

3. Isjoni. 2010. Cooperative Learning Effectiveness of Group Learning. Bandung: Alfabeta.

4. Masyhud, S. 2014. Educational Research Methods. Jember: Institute for Management Development and Profession Education.

5. Salim, A. 2005. Theory and Paradigm of Social Research. Semarang: Tiara Wacana.

6. Somantri, M. N. 2001. Initiating Renewal of School Science Education. Bandung: PT. RemajaRosdaKarya.

7. Wiriaatmadja. 2002. History Education in Indonesia Local, National and Global Perspectives. Bandung: HistoriaUtama Press. 